\title{
An Abhidharmic Theory of Welfare
}

Javier Hidalgo

Abstract: Do Buddhist philosophical commitments support a particular theory of well-being? Most authors who have examined this question argue that Buddhist ideas are compatible with multiple theories of well-being. In this paper, I contend that one tradition of Buddhist philosophy - Abhidharma - does imply a specific theory of welfare. In particular, Abhidharma supports hedonism. Most Ābhidharmikas claim that only property-particulars called dharmas ultimately exist and I argue that an Abhidharmic theory of well-being should only refer to these properties. Yet the only dharmas that could plausibly be intrinsically good are phenomenal properties that are good in virtue of how they feel. Thus, the only intrinsically good things are pleasures. I defend this surprising conclusion from various interpretative objections and show that my argument can also inform contemporary philosophical debates about welfare. Keywords: Buddhism; Abhidharma; well-being; hedonism

\section{Introduction}

Lives can go better or worse. Some lives are good. Others are disasters. What distinguishes these lives from each other? A theory of well-being helps answer this question. In particular, a theory of well-being tells us what sorts of things are intrinsically good for us. But which things are intrinsically good for us? Some philosophers endorse hedonism, the view that the only intrinsic good is pleasure. Others argue that the satisfaction of your desires is what benefits you. Still others defend an objective list theory of welfare. According to objective list theories, certain states like virtue or awareness of beauty are good for people irrespective of whether people desire these goods. There are more theories of welfare as well. 
Here is my question in this paper: which theory of welfare should Buddhists endorse? Few philosophers have explored this question. But those who have conclude that Buddhism is indeterminate between theories of welfare. In an insightful article, Stephen Harris (2014) argues that most contemporary theories of welfare are, in broad strokes, consistent with Buddhist commitments. Harris concludes: "Buddhist texts underdetermine which [theory of welfare] would have been accepted by ancient Indian Buddhists" (p. 2). Christopher Gowans (2016) claims: "Buddhist thought has much to say about well-being, but little that could be considered a philosophy of well-being" (pp. 78-9). Gowans suggests that Buddhist thought is practical in orientation. As a result, Buddhist philosophers felt little need to come up with a philosophical account of welfare. While Gowans concludes that Buddhism is likely inconsistent with desiresatisfaction theories, he contends that Buddhism is compatible with most other contemporary theories of well-being, such as objective list and nature-fulfillment theories.

In this paper, I will argue that one tradition of Buddhist philosophy-Abhidharma-does imply a specific theory of welfare. Abhidharma supports hedonism. My argument goes like this. Abhidharma holds that ultimately reality consists in simple entities called dharmas. A theory of well-being should only refer to entities that ultimately exist. So, a theory of well-being should only refer to dharmas. The only dharmas that could plausibly be intrinsically good are phenomenal properties that are good in virtue of how they feel. Phenomenal properties that are good in virtue of how they feel are pleasures. Thus, the only intrinsically good things are pleasures. It follows that Abhidharma is committed to hedonism. I have organized the paper as follows. In section 2, I will sketch my main argument for the claim that Abhidharma entails hedonism. In section 3, I will respond to several objections. Section 4 will consider the 
implications of my argument for debates about well-being in contemporary philosophy. In section 5 , I will conclude the paper.

\section{The Abhidharmic Case for Hedonism}

Abhidharma is an early tradition of Buddhist thought that sought to systematize the Buddha's teaching. Abhidharma texts are commentaries that aim to give a comprehensive presentation of the Buddhist worldview. As part of this project, Abhidharma texts suggest an ontology, an understanding of what reality consists in. I will now briefly sketch out this ontology.

Abhidharma says that the constituents of reality are dharmas. Dharmas are the building blocks out of which everything else is composed. In his Abhidharmakośa, Vasubandhu (2012) defines a dharma as "that which upholds or sustains (dhärana) its own characteristic or a particular inherent characteristic (svalakșaṇa)" (p. 206). Dharmas are entities that bear their own intrinsic nature (svabhāva). But dharmas are not tiny particles. Dharmas are propertyparticulars. ${ }^{1}$ They are properties like redness, wetness, heat, and hardness. Moreover, dharmas are not universals. Consider the universal "redness." If the universal "redness" exists, then this universal could inhere in multiple objects, like tomatoes and strawberries. In contrast, dharmas are only present in particular places and times, such as in this particular patch of redness. The Sautrāntikas and other schools of Abhidharma hold that dharmas are momentary. Dharmas appear and disappear in rapid succession.

Why does Abhidharma hold that the fundamental elements of reality are dharmas? One reason is that Abhidharma endorses mereological nihilism (Siderits, 2007, pp. 105-111). 
Mereological nihilism is the view that composite entities are unreal. Once again, let us turn to Vasubandhu's Abhidharmakośa. Vasubandhu writes:

The cognition [buddhi] of a pitcher ends when the pitcher is broken; the cognition of water ends when, in the mind $[d h \bar{l}]$, one analyzes [anyāpoha] water. The pitcher and the water, and all that resembles them, exist relatively or conventionally. The rest exists absolutely. (Vasubandhu, 2012, p. 1891)

Vasubandhu suggests that, if you can break something down into parts, even if only in the mind, then this thing does not ultimately exist. You can break the pitcher into parts. So, a pitcher is a composite object. If we assume mereological nihilism, then the pitcher lacks ultimate existence. But things are different with dharmas. Dharmas are non-extended simples. As a result, we are unable to break apart dharmas or reduce dharmas to anything else. This means that only dharmas have ultimate existence.

To sum up, Abhidharma advances the following picture of reality. Most of the world that we observe is illusory. This is so because the objects that we see and touch are composites. Hence, these objects are unreal. Instead, only partless and fleeting dharmas exist. Obviously, this ontology is revisionary. Yet Ābhidharmikas can partly accommodate commonsense by appealing to a distinction between conventional and ultimate reality. Ābhidharmikas claim that, while our commonsense beliefs are ultimately false, some of our ordinary beliefs are conventionally true. Recall Vasubandhu's pitcher. According to Vasubandhu, it is ultimately false that the pitcher exists. Nonetheless, Vasubandhu claims that statements about the pitcher can be true in a sense. These statements can be conventionally true.

But what is the difference between ultimate and conventional truths? Let us start with ultimate truths. Here is a first pass: a statement is ultimately true if and only if it both 
corresponds to the facts and neither asserts nor presupposes the existence of what is not ultimately real (Siderits, 2016, p. 16). ${ }^{2}$ Ultimate truths tell us how the world is at the most fundamental level. For this reason, statements that refer solely to dharmas can express ultimate truths. That is because dharmas are ultimately real. Yet statements about composite objects fail to express ultimate truths. For example, a statement about persons must be false from the ultimate perspective since persons, like all composite objects, are conceptual superimpositions on everchanging dharmas.

Now consider conventional truths. I will adopt the following interpretation of conventional truth: a statement is conventionally true if and only if it reliably leads to successful practice. ${ }^{3}$ Here is an illustration. My car lacks ultimate existence since my car is a composite entity. But it is useful for me to talk as if my car were real. This allows me to communicate efficiently with others. When I take my car to the mechanic, I can say "the engine lights on my car are on." The mechanic can understand me and fix the problem. I can then use my car to drive to work. It would be far more cumbersome for me to communicate facts about my car's engine lights in terms of dharmas. How could I communicate the ultimate truth about my car? Perhaps: "At time 9:45.00001, there are 1089000 dharmas occupying this space arranged in such and such relation with one another...." If I tried to communicate the truth about my car in terms of dharmas, my car would never get fixed. So, the sentence "my car's engine lights are on" is conventionally true despite the fact that it is ultimately false.

This completes my initial sketch of Abhidharma. To make this sketch, I have papered over complexities and disagreements among Abhidharma schools. ${ }^{4}$ But, with this background on the table, I will proceed with the rest of my argument. To prepare the way, I will first introduce some distinctions about welfare. 
A theory of welfare specifies which states of affairs are good for us in a non-derivative way. ${ }^{5}$ In other words, a theory of welfare tells us which states of affairs are intrinsically good for us. Suppose that I have an extremely painful and debilitating disease. Fortunately, there is a cure. I take it and, as a result, the disease goes away. My life is now filled with good things like pleasure, good friendships, achievement, the satisfaction of my desires, happiness, and the list goes on. We can say the following about this scenario. The cure had instrumental value. This is so because the cure led to me getting a list of good things: pleasure, friendship, achievement, etc. Yet some of the items on this list do not merely have instrumental value. Some of the items on this list are good not only because they get me something else. Some of these items are good in themselves. I will refer to the items that are intrinsically good as value atoms.

Competing theories of well-being put forth different value atoms. Obviously enough, desire satisfactionism says it is in itself good for you for your desires to be satisfied. The value atoms are the satisfaction of desires. Objective list theories specify a plurality of value atoms. An objective list theory holds that your life goes better in one respect if you get the goods on the list, which may include goods like loving relationships, knowledge, and autonomy. Furthermore, objective list theorists claim that your life goes better if you accrue goods on the list even if you lack a favorable attitude toward these goods. Suppose that loving relationships leave you cold. It may be intrinsically good for you to be in loving relationships nonetheless. Finally, hedonism is the view that the sole value atom is pleasure. Here is one way to think about hedonism: it is an objective list theory of welfare, but the list is very short. I will have more to say about hedonism in a moment.

So, theories of well-being advance many different possible value atoms. Out of all of these possibilities, which value atoms are actually intrinsically valuable? If the Abhidharma 
picture of reality is correct, then there is a constraint that should govern our selection of value atoms. The constraint is:

Existence Constraint. For any candidate value atom $a, a$ is intrinsically good only if $a$ ultimately exists.

So, for something to count as intrinsically valuable, it must ultimately exist. Here is my argument for the existence constraint. Assume that some value atom $a$ is intrinsically valuable. Either it is an ultimate truth that $a$ is intrinsically valuable or it is conventionally true that $a$ is intrinsically valuable. Yet the latter option faces a circularity. Therefore, value atoms must ultimately exist. I will now unpack this argument. According to the definition of conventional truth that I have adopted, a statement is conventionally true if and only if it reliably leads to successful practice. What counts as successful practice? Here is a straightforward interpretation: a practice is successful only if it promotes well-being. Consider the example of my car again. It is conventionally true that my car exists because grouping together the bundle of dharmas and referring to them as my car is useful. If I can make statements about my car, I can convince the mechanic to fix it, which makes me better off. I can now drive to work, get groceries, drive to the hospital if necessary, and so on. And the same goes for other people. The practice of grouping together certain dharmas and applying the concept "car" to them promotes well-being in the aggregate. This explains why it is conventionally true that cars exist.

Now consider statements that are conventionally false. Here is an example: "evil spirits cause disease." Suppose that we believe that evil spirits explain why diseases occur rather than, say, viruses or bacteria. This belief will likely make us worse off. We might spend time and resources on performing rites that aim to appease evil spirits when we could instead invest these resources in vaccinations, antibiotics, and public health campaigns. Once again, the difference 
between statements that are conventionally true and those that are conventionally false rests on facts about which practices effectively promote welfare.

So, conventional truth relies on a theory of well-being. However, if conventional truth relies on a theory of welfare, then we are unable to appeal to conventional truth in order to specify this theory of welfare. If the notion of conventional truth depends on an understanding of well-being, then it would be circular to come up with a theory of well-being at the level of conventional truth. The only way to avoid this circularity is to specify our theory of well-being at the level of ultimate truth. Therefore, any true statement of the form " $a$ is a value atom" must express an ultimate truth. And, if value atoms must ultimately exist, then it follows that the existence constraint is correct.

Yet, according to most Abhidharma schools, the only things that ultimately exist are dharmas. Thus, the value atoms in an Abhidharmic theory of well-being must be dharmas. This constraint rules out the value atoms that most contemporary theories of well-being propose because these value atoms are composite. To demonstrate this point, we will start with desire satisfaction theories of welfare. As we have seen, the value atoms for these theories are the satisfaction of desires. But what are desires? One popular story is that a desire is a relation between a subject and a proposition (McDaniel \& Bradley, 2008). Different theories of desires fill in this relation in different ways. For example, a dispositional account of desires says that for subject $\mathrm{S}$ to desire proposition $\mathrm{P}$ is for $\mathrm{S}$ to have a disposition to perform actions that bring about P under certain conditions. So, if I desire a sandwich, then I have the disposition to buy the ingredients for a sandwich, go to a restaurant and order a sandwich, and so on. But notice that desires are composite entities on this analysis. They are made up of subjects, relations, and 
propositions. Thus, if the existence constraint is true, then desire satisfactions cannot be value atoms, as desires lack ultimate existence.

Next consider objective list theories of welfare. Objective list theories claim that a list of different goods contribute to welfare. Some items that often show up in objective list accounts of welfare include the development of one's abilities, friendship and community, knowledge, moral goodness and virtue, self-respect, achievement, and pleasure (Fletcher, 2016). Yet these items, with the possible exception of pleasure, refer to composite entities. For one thing, most of them assume a subject who can bear the properties in question. To take a few obvious examples, items like friendship and development of one's abilities require the existence of persons who can form friendships and develop their abilities. Other items, like knowledge or virtue, are complex dispositions or psychological states. All of these candidate value atoms are non-starters if the existence constraint is correct and only dharmas are ultimately real. ${ }^{6}$

Phenomenal properties, though, can satisfy the existence constraint. Phenomenal properties are aspects of experience. They are what it is like to be in a certain state. Consider the experience of putting your hand in cool water. If you do this, you feel a complex cluster of sensations. You can experience the wetness of the water, its coolness, its movement, and so on. Facts about phenomenal properties seem different from other kinds of facts, like facts about the temperature of the water or the physics of how your hand interacts with the water.

One phenomenal property is hedonic tone. Hedonic tone is the affective part of experience that feels good or bad. Some authors describe hedonic tone as a glow or aura that pervades experience and that we can distinguish from the cognitive, emotional, and conative aspects of experience (Labukt, 2012, p. 175). The ancient Buddhist term for this phenomenal property is vedanā. Bhikkhu Bodhi describes vedanā as follows: 
[V]edana $\bar{a}_{. .}$is the mental factor that feels the object: it is the affective mode in which the object is experienced. The Pali word vedanā does not signify emotion (which appears to be a complex phenomenon involving a variety of concomitant mental factors), but the bare affective quality of an experience, which may be either pleasant, painful or neutral. (Bodhi, 2003, p. 80)

As Bhikkhu Bodhi points out, vedanā can feel painful, indifferent, or pleasant. For ease of reference, I will refer to vedanā with a pleasant valence as "pleasure."

Vedana $\bar{a}$ is a dharma. That is because vedana is indivisible and irreducible. Remember that Abhidharma holds that, if we are unable to decompose something into parts, then this thing is ultimately real. Vasubandhu (2012) notes that this criterion of indivisibility implies that physical form ( $r \bar{u} p a)$ is real because physical form is irreducible. Even if we reduce physical matter into its component parts, then "the cognition of the intrinsic nature [svabhāva] of visible form persists." Vasubandhu adds: "Sensation [vedana] , etc., is also to be seen in the same way" (p. 1892). The idea here is that we are unable to reduce sensation to anything else. If we try to decompose $v e d a n \bar{a}$ into its parts, the idea of vedanā will persist. So, vedanā is part of the bedrock of ultimate reality. And, if vedana is a dharma, then it can satisfy the existence constraint.

Furthermore, vedan $\bar{a}$ with a positive valence is an intrinsic good. The justification for this claim is intuitive. Pleasures are good in virtue of how they feel. And your experience of feeling pleasure gives you a reason to believe that pleasures are good. Consider the following scenario. Imagine that an evildoer has implanted a device in your brain that inhibits all pleasure. As long as this device is in place, you will never experience a positive hedonic tone again. Suppose that, instead, your hedonic tone is perfectly flat. Nonetheless, you are capable of living your life much 
as before. You can continue to pursue your projects, look after your children, acquire knowledge, and so on. Pretty much everyone would agree that the device is terrible for you. You have lost something crucial after the evildoer implanted this device. That is because this device prevents you from experiencing something that is good: pleasure.

Most of us can agree that pleasure is an intrinsic good. Yet hedonism makes a stronger claim. Hedonism says that the only intrinsic good is pleasure. More precisely, hedonism is the view that any two beings who are identical in what pleasures and pains they felt during their lives must also be identical in any respects in which they were well and poorly off in their lives (Bramble, 2016, p. 87). Suppose that Sam and his twin Bradley have equal amounts of pleasures and pain in their lives. If hedonism is true, then Sam and Bradley are equally well off regardless of whether one of them has more virtue, knowledge, or appreciation of beauty than the other. Why believe that Abhidharma supports hedonism in this sense?

The reason is that no other dharma is a plausible candidate for an intrinsic good besides vedanā. Take the mental dharmas. Buddhists claim that there are universal mental dharmas present in every experience. Besides vedana $\bar{a}$, these include mental factors like contact, attention, discernment, perception, and volition. But none of these items seem good in themselves. Consider perception (saññ $\bar{a}$. It is hard to see why the bare state of perception could be valuable. Or take volition $(c e t a n \bar{a})$. Cetana $\bar{a}$ is the mental factor that coordinates the other mental factors in order to achieve goals. Yet it is unclear what is intrinsically valuable about the mere coordination of mental factors. At least, the value of cetana depends on the value of the goal that the mental factors seek to achieve. If cetana leads to skillful actions, then it is good. But this is only extrinsic goodness, not the intrinsic kind. The value of cetana is derived from the value of something else. I concede upfront that I lack a watertight argument for the view that the only 
dharma that is intrinsically valuable is vedana . However, my motivated hypothesis is that, if you run through the list of dharmas, you will find that none of them are compelling candidates for intrinsic goods. Only vedanā remains.

Another reason to think that Abhidharma supports hedonism is that the Abhidharma's tenets rule out classic objections to hedonism. Hedonism says that a person's well-being is equal to the sum of pleasures that her life contains. But many philosophers reject this view. They deny the value of a life is equal to the sum of its parts. Some believe that the trajectory of a life matters. Perhaps it makes a life go better if this life improves over time rather than declining. Other authors believe that the variation of a life matters. On this view, a life is better if it contains more variety, everything else being equal. These accounts of well-being depart from the summative view in hedonism.

To explain why the summative component of hedonism is false, critics appeal to organic unities. An organic unity is something whose value is different from the value of the sum of the intrinsic value of its parts. Classic examples of organic unities are appreciation of beauty and desert. G.E. Moore claims that, while a beautiful object has little value by itself, this object becomes valuable when combined with a pleasant consciousness of this object (Heathwood, 2013; Moore, 2004). Or consider deserved punishment. Punishment produces pain, which is bad. But deserved punishment combines with this suffering to produce an overall good. So, defenders of organic unities can concede that pleasure is valuable and nonetheless deny that it is the sole value, as there are organic unities whose value is greater than summation of pleasures.

Yet these alternatives to hedonism fall flat given mereological nihilism. If mereological nihilism is true, then wholes are unreal. If wholes are unreal, then there are no organic unities. After all, organic unities are wholes. Therefore, the value of any state of affairs is the sum of the 
intrinsic values of its parts. Now, assume that I have established that only vedana with a positive valence is an intrinsically valuable dharma. If there are no organic unities, then hedonism follows. The value of well-being is merely the sum of pleasures. The objection from organic unities fails to get off the ground. In section 4, I will show how Buddhist commitments can help rebut other prominent objections to hedonism as well.

Before I conclude this section, I will recap my overall argument for the conclusion that Abhidharma entails hedonism. My argument goes like this:

1. The only things that ultimately exist are dharmas.

2. For any candidate value atom $a, a$ is intrinsically good only if $a$ ultimately exists.

3. So, value atoms must be dharmas.

4. The only dharmas that could plausibly be value atoms are pleasures (vedana with a positive valence).

5. So, the only value atoms are pleasures.

Let me comment on the key premises of this argument. The first premise is just a description of Abhidharma ontology, which I have assumed throughout the paper. Premise 2 is the existence constraint. To recap, the existence constraint is justified because, if Ābhidharmikas reject this constraint, then their theory of well-being becomes circular. I have defended premise 4 through a process of elimination. Every other mental dharma besides positive hedonic tone is unlikely to possess intrinsic value, although it may have extrinsic value. The upshot of this argument is hedonism. Thus, if my argument is correct, then Abhidharma entails hedonism.

\section{Interpretative Objections}


I will now consider some objections to my argument. These objections are interpretive. They say that I have misinterpreted the commitments and tenets of Abhidharma or Buddhism as a whole.

Here is the first objection. Buddhist texts often disparage pleasure. For example, in the Māgaṇiya Sutta, the Buddha says:

$[\mathrm{I}] \mathrm{n}$ the past sensual pleasures were painful to touch, hot, and scorching; in the future sensual pleasures will be painful to touch, hot, and scorching; and now at present sensual pleasures are painful to touch, hot, and scorching. But these beings who are not free from lust for sensual pleasures, who are devoured by craving for sensual pleasures, who burn with fever for sensual pleasures, have faculties that are impaired; thus, though sensual pleasures are actually painful to touch, they acquire a mistaken perception of them as pleasant. (Ñānamoli \& Bodhi, 1995, p. 612)

A straightforward reading of this passage is that pleasure is bad. After all, it describes pleasures as "scorching" and implies that beings who experience pleasure are deluded. We can find many similar passages in Buddhist scriptures. We might infer from these texts that Buddhist hedonism is a non-starter.

Yet it would be too quick to conclude that Buddhists condemn pleasure per se. That is because we can also find early Buddhist writings that say that pleasure is good. Here is one example. In the $C \bar{u} l a d u k k h a k k h a n d h a$ Sutta, the Buddha brags that he is capable of experiencing more pleasure than a king. In particular, the Buddha compares himself with the King Bimbisāra, the king of Magadha. The Buddha says: "I can abide without moving my body or uttering a word, experiencing exclusively pleasure for one day and night...for two, three, four, five, and six days and nights...for seven days and nights. What do you think, friends? That being so, who 
dwells in greater pleasure, King Seniya Bimbisāra of Magadha or I?” The Buddha's interlocutor, Mahānāma the Sakyan, responds: "That being so, the venerable Gotama abides in greater pleasure than King Seniya Bimbisāra of Magadha" (Ñānamoli \& Bodhi, 1995, p. 189). This is not the only Buddhist scripture where the Buddha suggests that pleasure is good. Elsewhere, the Buddha says that enlightened beings experience "delight" and that pleasure arises in a "welltaught noble discipline" (Ñānamoli \& Bodhi, 1995, p. 334). Buddhist texts also generally extol the value of certain kinds of pleasures, such as sympathetic joy in the good fortune of others (muditā). ${ }^{7}$

What is going on here? Here is my diagnosis: the problem with pleasure is that pleasure often leads to craving and attachment. Craving and attachment cause suffering because the things that give us pleasure are impermanent. Suppose your ability to run marathons gives you a great deal of pleasure. Because you like pleasure and want more of it, you will likely become attached to your health and your athletic ability. But those things will go away with time. Perhaps you will suffer an injury. Or you will just get old. The end result is that the object of your attachment will disappear. This may cause you to experience anxiety, sadness, frustration, and other negative states. The upshot is that your craving for pleasure results in suffering. And the same goes for any object of pleasure. We become attached to this pleasure. Given the impermanence of all things, the implication of attachment is anxiety, frustration, and pain.

Yet Buddhists contend that we can avoid attachment and craving if we adopt the right practices. Through rigorous mediative and ethical techniques, aspirants on the Buddhist path can undo the clinging that generates suffering. In the Mahäsaccaka Sutta, the Buddha says:

And how, Aggivessana, is one developed in body and developed in mind? Here, Aggivessana, pleasant feeling arises in a well-taught noble disciple. Touched by that 
pleasant feeling, he does not lust after pleasure or continue to lust after pleasure. That pleasant feeling of his ceases. With the cessation of the pleasant feeling, painful feeling arises. Touched by that painful feeling, he does not sorrow, grieve, and lament, he does not weep beating his breast and become distraught. (Ñānamoli \& Bodhi, 1995, p. 334) Pleasure and pain pass through the mind of an enlightened being (an arhat) without either clinging or aversion. Thus, for an advanced disciple, pleasure is no longer bad because pleasure fails to generate craving and attachment. With this analysis in hand, we explain why the condemnation of sensual pleasure in Buddhist texts is compatible with the view that pleasure is intrinsically good. Buddhists can say that, while pleasure is intrinsically valuable, it is often instrumentally bad since it causes us to form attachments and cravings that cause suffering. But pleasure ceases to be instrumentally bad with the proper training and discipline.

Consider another interpretive objection. An objector might argue that Abhidharma can identify other goods as intrinsically valuable besides pleasure. This objection begins with the observation that Ābhidharmikas often refer to certain dharmas as skillful or wholesome (kuśala) and unskillful or unwholesome (akuśala). For example, they claim that dharmas like right concentration (samyak-samādhi) and compassion (karunāa) are skillful, while dharmas such as greed (lobha) and delusion (moha) are unskillful. ${ }^{8}$ An objector may then argue that the distinction between skillful mental factors and unskillful ones tracks the distinction between intrinsically good and bad dharmas. If that is true, then it is false that Abhidharma supports hedonism, as many of the mental factors that Ābhidharmikas describe as wholesome are not pleasures in any straightforward sense. Consider the fact that some skillful mental factors like non-greed (alobha) and non-delusion (amoha) are not pleasures in any straightforward sense. So, 
if mental factors that are not pleasures can be intrinsically good, then Abhidharma implies that hedonism is false. After all, hedonism holds that the only intrinsic good is pleasure.

This objection misfires. Here is the problem: it is wrong to assume that the kuśalaakuśala distinction tracks the distinction between intrinsic goods and bads. In fact, Buddhist philosophers - and ancient Indian thinkers in general-did not clearly distinguish between intrinsic and instrumental value (Goodman, 2014, p. 127). As a consequence, it is ambiguous in any given case whether a dharma is skillful because it is intrinsically valuable or it is skillful because it is instrumentally valuable. Consider an example: fear of wrongdoing (Pāli: ottappa). Abhidharma texts refer to fear of wrongdoing as kuśala. But fear of wrongdoing only has instrumental value. If you fear wrongdoing, then you are less likely to perform harmful actions. It is hard to see how there is anything intrinsically valuable about fear of wrongdoing. The same lesson applies to other skillful mental factors. The upshot is that Buddhist writers may refer to a mental factor as kuśala even though it lacks intrinsic value and merely has instrumentally value. As a result, we are unable to infer that a dharma is intrinsically good from the fact that Ābhidharmikas describe it as kuśala. While Ābhidharmikas identify many different dharmas as kuśala, that is consistent with the possibility that there is only one intrinsic good.

To be clear, I have refrained from claiming that ancient Indian Buddhists endorse hedonism. They do not. Moreover, it would probably be anachronistic to claim that ancient Buddhists favor any contemporary theory of welfare. Instead, my argument is that Ābhidharmikas accept certain philosophical positions that support hedonism and that there is nothing in Buddhist commitments that rule this implication out.

\section{Implications for Contemporary Debates}


That completes my argument for the conclusion that Abhidharma supports hedonism. I will now consider some implications of my arguments for contemporary debates about welfare in Western philosophy.

Hedonism is an unpopular view among philosophers. Although some philosophers defend hedonism, most reject it. Yet, if hedonism is false, then Abhidharma is in trouble. If hedonism is false and Abhidharma implies hedonism, then we should reject Abhidharma. But I am now going to explore whether Abhidharma has the resources to rebut popular objections to hedonism. My goal is not to rebut every major objection to hedonism. Instead, my more modest aim is to consider two prominent objections to hedonism and assess whether an Ābhidharmika who accepts my argument for hedonism can rebut these objections. If these responses are promising, then my discussion will help to show that Abhidharma can contribute to contemporary philosophical debates about well-being.

\section{A. The Heterogeneity Objection}

I have argued that Abhidharma supports the view that only the phenomenal aspects of experience with a pleasant valence are intrinsically good. Contemporary philosophers refer to this account of pleasure as a felt-quality theory. A felt-quality theory holds that some sensation counts as a pleasure or a pain just in virtue of its phenomenology - that is, how this sensation feels. Since that is also what Abhidharmic hedonism says, it is committed to a felt-quality theory of pleasure.

Yet felt-quality theories of pleasure face an important objection called the heterogeneity objection. This objection says that there is no such thing as "pleasure" if we understand pleasure as a phenomenal quality. There are only a variety of different phenomenal qualities that we 
group together under the category "pleasure" and that this grouping lacks unity. Derek Parfit makes this objection. Parfit (1986) writes: "Compare the pleasures of satisfying an intense thirst or lust, listening to music, solving an intellectual problem, reading a tragedy, and knowing that one's child is happy. These various experiences do not contain any distinctive common quality" (p. 493). Here is another way of describing the objection. ${ }^{9}$ If a felt-quality theory is true, all pleasures feel alike in some way. But it is false that all pleasures feel alike in some way. So, feltquality theories of pleasure are false. Philosophers who raise the heterogeneity objection usually take it to show that we should endorse an attitude-based theory. According to an attitude-based theory, some phenomenology counts as a pleasure if the subject has a favorable attitude toward it.

Could a defender of Abhidharmic hedonism concede the point and accept an attitudebased account of pleasure? No. The problem is that an attitude-based theory of pleasure fails to satisfy the existence constraint. If an attitude-based theory is correct, then what it is for a sensation to count as pleasure is for this sensation to be liked by some subject. But now pleasure is a complex and composite entity. It consists in a subject's attitude of liking along with a piece of phenomenology toward which this liking is directed. If an attitude-based theory is right, then pleasure is ultimately unreal. Thus, it is unable to function as a value atom in a theory of wellbeing. This leaves a felt-quality theory as the only option for Abhidharmic hedonism. Consequently, a defender of this view must find a way to rebut the heterogeneity objection. Defenders of felt-quality theories have responded to the heterogeneity objection in several different ways. Here I will consider just one possible response. Felt-quality theorists should challenge the premise that, if a felt-quality theory is true, all pleasures feel alike in some way. Felt-quality theorists should reject this premise and concede that there is not only one 
pleasant phenomenal quality. Rather, there are many pleasant phenomenal qualities. Some philosophers compare hedonic tones to the experience of seeing different colors (Crisp, 2008, p. 109). The experience of seeing blue is irreducibly different from the experience of seeing yellow, although these experiences share a similar phenomenology. In the same way, felt-quality theorists can embrace pluralism about hedonic tones. They say that we experience many different hedonic tones that share a similar phenomenology and we group together these tones under the general term "pleasure." What entitles us to call these different hedonic tones pleasure? They are all experiences that are intrinsically good in virtue of how they feel (Labukt, 2012, p. 189).

Contemporary philosophers have developed a pluralistic response to the heterogeneity objection in detail. But Abhidharma metaphysics can add something to their response. They can give us a deeper explanation of why it is unreasonable to expect that there is one quality that is universal across all pleasant experiences. To see why, note that certain schools of Abhidharma, particularly the Sautrāntikas, actually reject the existence of universals altogether (Vasubandhu, 2012, pp. 557-9). For example, Vasubandhu considers the dharma of homogeneity (sabhāgatā). This dharma is a universal that is instantiated in all living beings and explains the resemblances between them. While other schools like Vaibhasikas entertain the existence of universals, Vasubandhu denies that homogeneity is a dharma. He argues that we are unable to directly perceive homogeneity and that we also cannot infer that homogeneity exists since this dharma lacks a causal function. Moreover, positing universals generates an infinite regress because we would need to assume new universals to account for the similarities between universals.

So, the Sautrāntikas contend that universals are merely conceptual imputations and that only particulars exist. But, if only particulars are real, then how do we form concepts that generalize across particulars? Later Buddhist epistemologists, particularly Dignāga and 
Dharmakīrti, suggest an answer. They advance an apoha theory that aims to explain how we construct universals from our experience. The details of apoha theory are complex. For our purposes here, the key idea is that we construct universal on a pragmatic basis. We focus on causal properties of objects that are relevant to our purposes and interests, and ignore the differences across particulars. Universals are conceptual fictions that facilitate our purposes and enable effective action. ${ }^{10}$

The upshot is that every grouping of particulars into universals is conventional and, in a sense, arbitrary. Universals fail to track natural kinds because natural kinds are fictions too. As every grouping is conventional, then there is no mistake if we group together a multitude of different and particular hedonic tones under the general term "pleasure" in order to serve our interests in describing a theory of welfare. That is how all categorization and concept formation works. Recall that one premise of the heterogeneity objection is that, if a felt-quality theory is true, all pleasures feel alike in some way. But, since universals are unreal, we should not expect to find a universal quality inherent in all pleasant experiences. Rather, we should expect only an innumerable variety of particular hedonic tones, one after the other. And that is what we find.

\section{B. The Experience Machine Objection}

Probably the most influential objection to hedonism in contemporary philosophy is the experience machine objection, which many believe yields a refutation of hedonism. In his famous presentation of this objection, Robert Nozick writes:

Suppose there were an experience machine that would give you any experience you desired. Superduper neuropsychologists could stimulate your brain so that you would think and feel you were writing a great novel, or making a friend, or reading an 
interesting book. All the time you would be floating in a tank, with electrodes attached to your brain. Should you plug into this machine for life...? ... Would you plug in? What else can matter to us, other than how our lives feel from the inside? (Nozick, 2013, pp. 42-3)

Here is one interpretation of the experience machine objection ${ }^{11}$ :

1. If hedonism is true, then your welfare would be higher if you plugged yourself into the experience machine than if you refused to plug yourself in.

2. It is false that your welfare would be higher if you plugged yourself into the experience machine than if you refused to plug yourself into the experience machine.

3. Therefore, hedonism must be false.

The first premise of the argument seems true. Although some hedonists have challenged this premise, it is hard to rule out the possibility that, regardless of how much pleasure your life contains now, your life would have even more pleasure in the experience machine.

But what about the second premise? Why should we reject the view that your welfare would be higher if you plugged yourself into the experience machine? Nozick writes:

First, we want to do certain things, and not just have the experience of doing them. In the case of certain experiences, it is only because first we want to do the actions that we want the experiences of doing them or thinking we've done them.... A second reason for not plugging in is that we want to be a certain way, to be a certain sort of person. Someone floating in a tank is an indeterminate blob. There is no answer to the question of what a person is like who has been long in the tank. Is he courageous, kind, intelligent, witty, loving? It's not merely that it's difficult to tell; there's no way he is. (Nozick, 2013, p. 43) 
Finally, Nozick argues that plugging into the experience machine prevents us from making contact with deeper reality. Yet many of us "desire to leave themselves open to such contact [with reality] and to a plumbing of deeper significance." Nozick concludes that more matters to us than the quality of our experiences or how our experiences feel from "the inside."

To sum up, Nozick's argument for the second premise of the experience machine objection goes:

(A) We want to be agents that perform real actions, to be certain sorts of people with good qualities, and to be in contact with deeper reality.

(B) If we plugged into the experience machine, then these desires would be frustrated and, if we refused to plug into the experience machine, then desires may be satisfied.

I will now object to claim (B). I will argue that, if we accept certain Buddhist assumptions, then we are also unable to satisfy the desires in (A) even if we are outside of the experience machine. If so, then the fact that we have the desires in (A) fails to give us a reason to refrain from plugging into the experience machine. The deeper diagnosis of where Nozick's argument goes wrong is that the desires in (A) are rooted in false beliefs. Some of these desires, such as the desire to become a genuine actor and to be a person with admirable properties, are predicated on the belief that we are selves. According to Buddhists, this belief is false. And our theory of welfare should not be sensitive to desires that depend on false beliefs.

Most of us think that we are selves. Roughly speaking, this means that we think of ourselves as entities that persist through time and that have thoughts, feelings, and experience while also being distinct from these mental states. If we are selves, then we are enduring mental substances that are the bearers and subjects of experience. Furthermore, we conceive of 
ourselves as doers and agents that act in the world and are, at the same time, separate from the rest of the world.

Buddhists argue that the belief in the self gives rise to self-grasping (ahamkāra) and selfmaking (asmimāna). In his Abhidharmasamuccaya, Asanga (2015) writes: "He who is fettered by pride does not understand the self and what pertains to the self. Not understanding them, he seizes the idea of self and what pertains to the self, performs unfavorable actions and does not perform favorable actions" (p. 99). In a similar way, Vasubandhu claims that non-Buddhists "conceptually construct the self as a separate substance" and "all of the afflictions have grasping after the self as their origin" (Gold, 2016, p. 99). Since we identify as selves, we become attached to our projects, interests, and desires. We grasp and appropriate our interests and desires as "me" and "mine." Yet this grasping rests on a mistake. Introspection and philosophical reflection reveal that there is no self. Instead, there is only a series of impermanent psychophysical elements (skandha). While our attachments and cravings are predicated on the existence of the self, the self turns out to be illusory.

My suggestion is that the desire to be a doer of deeds and to be "a certain sort of person" depends on a belief in the self. $I$ want to perform real actions and $I$ want to be a kind, witty, and insightful sort of person. The problem with these desires is that they refer to something that is unreal, an enduring "I" who can act as an agent and serve as a substance that claims ownership over qualities and characteristics. If the self lacks ultimate reality, then we are unable to satisfy these desires. Consider the desire to be a certain sort of person with admirable qualities. Ābhidharmikas would argue that, since persons are composite and thus ultimately unreal, it is impossible to be any sort of person. To use an analogy, suppose that I want the interior angles of a triangle to add up to 200 degrees. This desire is incapable of being satisfied regardless of 
whether I am in the experience machine. The interior angles of a triangle will never add up in the way that I want. If Buddhists are right, then the desire for the self to be a genuine agent and substance that bears properties is equally bound to be frustrated inside and outside of the experience machine. If this desire is unsatisfiable, then it fails to count as a reason to believe that welfare will be lower if people plug themselves into the experience machine.

An objector might respond that, while it is true that there are no selves or persons from the perspective of ultimate reality, persons and selves exist conventionally. Thus, conventionally speaking, we can be agents and we can take on enduring qualities. If that is true, then our desires to be agents with good qualities can be satisfied or frustrated, and it is plausible that these desires are frustrated in the experience machine. So, even if we assume Buddhist premises, we can still endorse claim (B).

Here is my response to this objection. I have assumed an understanding of conventional truth according to which some statement is conventionally true if and only if it's acceptance promotes well-being. But this account of conventional truth is a kind of fictionalism. We should think of ourselves as agents and persons if doing so brings about more welfare. These beliefs can be useful fictions. Yet Nozick's whole point is that we do not merely desire to think of ourselves as agents and enduring persons. We can think of ourselves as agents and persons in the experience machine too. Instead, Nozick is arguing that we want to actually be these things, and not merely think of ourselves as doers and selves. So, even if it is conventionally true that we are persons with selves, this still fails to satisfy the desires in claim (A). If we are unable to satisfy the desires in (A) outside of the experience machine, this gives us a reason to doubt claim (B).

Recall that Nozick gives another reason for why you should refuse to plug yourself into the experience machine besides the ones that I have discussed so far. He says that we want to 
have contact with reality. The experience machine prevents us from establishing this contact. So, we should refuse to plug ourselves into the machine. But an Ābhidharmika can also challenge Nozick's claim that, if we refuse to plug into the experience machine, we will have better contact with reality. Abhidharma suggests that our experience of the world is deceptive. We think that we perceive real and enduring objects. We tend to believe that we are surrounded by furniture, buildings, and people. All of these beliefs are ultimately false. These perceptions and beliefs are mere conceptual superimpositions on innumerable and momentary dharmas flashing in and out of existence. So, Abhidharma contends that much of our perception of the world is an illusion.

If our everyday experience of the world is illusory, then it is doubtful whether we stand in deeper contact with reality when we are outside of the experience machine than when we are in it. Ābhidharmikas do hold that we can discover the truth about reality through introspection and philosophical reflection. But notice that we can also discover the truth about reality in the experience machine. The same introspection and philosophical arguments are available to us there. Thus, once again, it seems false that we are in any better position to satisfy the desires in claim (A) outside of the experience machine as we are to satisfy them inside the machine.

I conclude that, assuming Buddhist premises, we should reject claim (B). If (B) is false, then the second premise of the experience machine objection lacks support. Maybe critics of hedonism can come up with another argument for this premise. But, until then, Abhidharmic hedonists have the resources to resist the experience machine objection.

\section{Conclusion}

The teachings of the Buddha offer a path to well-being. Those who traverse the Buddhist path and achieve awakening are said to attain immeasurable peace and happiness. ${ }^{12}$ What though 
is the nature of this well-being? What precisely does it mean for our lives to go well from a Buddhist perspective? To fully answer these questions, we need to articulate and defend a Buddhist theory of welfare.

Yet most philosophers who have examined the implications of Buddhist philosophical commitments for theories of welfare conclude that these commitments are indeterminate between different theories. I have defended a different conclusion. I have argued that the philosophical tradition of Abhidharma supports a hedonist theory of welfare. Furthermore, I have made the case that Abhidharma Buddhism has the resources to rebut certain objections to hedonism in contemporary philosophy. For sure, most contemporary philosophers would be inclined to reject my argument for hedonism. This is so primarily because most contemporary philosophers reject the broader framework of Abhidharma. But suppose that the Abhidharmic case for hedonism has the advantages that I have described. If so, then perhaps this is also a reason to give Abhidharma a more sympathetic assessment as a whole.

\section{References}

Asanga. (2015). Abhidharmasamuccaya: The Compendium of the Higher Teaching (W. Rahula \& S. Boin-Webb, Trans.). Jain Pub Co.

Bodhi, B. (Ed.). (2003). A Comprehensive Manual of Abhidhamma (B. Bodhi \& Nārada, Trans.; Buddhist Publication Society, Sri Lanka edition). BPS Pariyatti Editions.

Bradley, B. (2011). Well-Being and Death. Oxford University Press.

Bramble, B. (2016). A New Defense of Hedonism about Well-Being. Ergo, an Open Access Journal of Philosophy, 3. https://doi.org/10.3998/ergo.12405314.0003.004 
Buddhaghosa, B. (2003). The Path of Purification: Visuddhimagga (B. Nanamoli, Trans.). BPS Pariyatti Editions.

Chadha, M., \& Nichols, S. (2019). Self-Conscious Emotions Without a Self. Philosophers' Imprint, 19(38).

Collins, S. (2010). Nirvana: Concept, Imagery, Narrative. Cambridge University Press.

Cowherds, T. (2010). Moonshadows: Conventional Truth in Buddhist Philosophy. Oxford University Press.

Crisp, R. (2008). Reasons and the Good. Oxford University Press.

Dunne, J. D. (2011). Key Features of Dharmakīrti’s Apoha Theory. In M. Siderits, T. Tillemans, \& A. Chakrabarti (Eds.), Apoha: Buddhist Nominalism and Human Cognition (pp. 84108). Columbia University Press.

Fletcher, G. (2016). Objective List Theories. In G. Fletcher (Ed.), The Routledge Handbook of Philosophy of Well-Being (pp. 148-160). Routledge.

Gold, J. C. (2016). Paving the Great Way: Vasubandhu's Unifying Buddhist Philosophy. Columbia University Press.

Goodman, C. (2004). The Treasury of Metaphysics and the Physical World. The Philosophical Quarterly (1950-), 54(216), 389-401. JSTOR.

Goodman, C. (2005). Vaibhāṣika Metaphoricalism. Philosophy East and West, 55(3), 377-393.

Goodman, C. (2014). Consequences of Compassion: An Interpretation and Defense of Buddhist Ethics. Oxford University Press.

Gowans, C. (2016). Buddhist Understandings of Well-Being. In G. Fletcher (Ed.), The Routledge Handbook of Philosophy of Well-Being (pp. 70-80). Routledge. 
Harris, S. E. (2014). Suffering and the Shape of Well-Being in Buddhist Ethics. Asian Philosophy, 24(3), 242-259.

Heathwood, C. (2013). Organic Unities. In H. LaFollette (Ed.), The International Encyclopedia of Ethics. Wiley.

Labukt, I. (2012). Hedonic Tone and the Heterogeneity of Pleasure. Utilitas, 24(2), 172-199. Cambridge Core.

Lin, E. (2016). How to Use the Experience Machine. Utilitas, 28(3), 314-332.

McDaniel, K., \& Bradley, B. (2008). Desires. Mind, 117(466), 267-302.

Moore, G. E. (2004). Principia Ethica. Dover Publications.

Nozick, R. (2013). Anarchy, State, and Utopia. Basic Books.

Parfit, D. (1986). Reasons and Persons. Oxford University Press.

Siderits, M. (2007). Buddhism as Philosophy: An Introduction. Hackett Publishing Company, Inc.

Siderits, M. (2016). Personal Identity and Buddhist Philosophy (2 edition). Routledge.

The Middle Length Discourses of the Buddha: A Translation of the Majjhima Nikaya (B. Ñāṇamoli \& B. Bodhi, Trans.). (1995). Wisdom Publications.

Tillemans, T. (2018). Deflating the Two Images and the Two Truths. In J. L. Garfield (Ed.), Wilfrid Sellars and Buddhist Philosophy: Freedom from Foundations (pp. 80-96). Routledge.

Vasubandhu. (2012). Abhidharmakosa-Bhasya of Vasubandhu: The Treasury of the Abhidharma and Its Commentary (G. L. Sangpo \& D. L. V. Poussin, Trans.; 2012th edition). Motilal Banarsidass. 
Westerhoff, J. (2013). Metaphysical Issues in Indian Buddhist Thought. In S. M. Emmanuel

(Ed.), A Companion to Buddhist Philosophy (pp. 129-150). Wiley-Blackwell.

Westerhoff, J. (2018). The Golden Age of Indian Buddhist Philosophy in the First Millennium

CE. Oxford University Press.

\footnotetext{
${ }^{1}$ This interpretation of Abhidharma draws on Goodman, 2004.

${ }^{2}$ We can see this understanding of ultimate truth in the commentary to the Kathāvatthu of the Abhidharma Pitaka, which says "an ultimate statement is true in that it characterizes things as they are." This passage is translated in Tillemans, 2018, p. 82.

${ }^{3}$ A "pragmatist" account of conventional truth is defended in Goodman, 2005; Siderits, 2016; Westerhoff, 2013. There are, of course, several other accounts of conventional truth in the Buddhist tradition as well. But I'm sorry to say that I lack the space to adequately evaluate and compare the different accounts of conventional truth here. For various attempts to provide this comparison, see: Cowherds, 2010.

${ }^{4}$ For a discussion of the differences between various schools of Abhidharma, see Westerhoff, 2018, chapter 1. ${ }^{5}$ My discussion here draws on the framework presented in Bradley, 2011, chapter 1.

${ }^{6} \mathrm{~A}$ similar problem confronts other theories of welfare, such as nature-fulfillment theories of well-being. These theories hold that well-being consists in the perfection of the person. Obviously enough, these theories are nonstarters if the existence constraint is correct

${ }^{7}$ See, for instance, Buddhaghosa, 2003, chapter 9.

${ }^{8}$ For a list of the different factors that Ābhidharmikas describe as skillful or unskillful, see: Chadha \& Nichols, 2019 , p. 4.

${ }^{9}$ To reconstruct the heterogeneity objection, I have relied on Bramble, 2016, p. 91.

${ }^{10}$ For interpretations of apoha along these lines, see: Dunne, 2011.

${ }^{11}$ This interpretation of the experience machine objection draws on Lin, 2016.

${ }^{12}$ Buddhist scriptures describe nirvana as "best," "happiness," "immeasurable," "peaceful," and more. While the concept of nirvana is notoriously difficult to understand, these descriptions suggest that one who attains

enlightenment achieves a high level of well-being. See: Collins, 2010, p. 66.
} 